\title{
Simulation Learning Methods for Students' Understanding of Flood Disaster Preparedness Materials
}

\author{
Andi Irwan Benardi ${ }^{1, *}$ Jamhur $^{2,}$ Sriyono ${ }^{3,}$ Johan Hadi ${ }^{4,}$ Prisma Tia Ningrum ${ }^{5,}$ \\ Siti Nur Hasna Khofifah ${ }^{6}$
}

1,2,3,4,5,6 Geography, Faculty of Social Sciences, Universitas Negeri Semarang. *Corresponding author.Email: andy@mail.unnes.ac.id ${ }^{l}$

\begin{abstract}
Students need knowledge about prevention and preparedness. This study aims to see the learning process of the flood disaster, students' responsiveness to learning with the Simulation Learning method, and to see see to see what is learning students who get learning using the Simulation Learning method and student learning outcomes who get learning without using the method. The objectives of this research are (1) Knowing the implementation process of learning and understanding students, (2) Evaluating the effectiveness of learning, (3) Knowing knowledge in learning problem flood disaster mitigation. The population in this study were students of class XI SMA Negeri 8 Semarang which consisted of two classes that could be measured by 73 students. Samples were taken using purposive sampling technique. Collecting data using the method of documentation, observation, observation, and questionnaires. Data analysis was carried out by descriptive qualitative and descriptive proportions. The results of this study were (1) The implementation of learning and student understanding went very well with a score of $95.49 \%$, (2) The effectiveness of learning in the experimental class which obtained the cognitive aspects of learning outcomes score of $87.77 \%$ including very high criteria, the affective aspect of $90,74 \%$ including very high criteria, and cognitive aspects of $90.74 \%$ including very high criteria. (3) There is no security in implementing flood disaster mitigation learning.
\end{abstract}

Keywords: Learning Model, Simulation Learning, Disaster Mitigation, Flood.

\section{INTRODUCTION}

Education is a conscious effort to develop human quality, therefore education plays a very important role in educating the nation's life [1]. The progress of a nation depends on the quality of education that has been implemented in that country. Education will run well if all components work professionally. The teacher is an important component in the world of education. Education will run well if teachers have adequate teaching competencies. One of the professional teacher competencies is in choosing the most appropriate learning method for students. One of the criteria for teachers who are successful in choosing the appropriate classroom learning method is from student learning outcomes that meet the Minimum Completeness Criteria (KKM), including one of which is the use of learning methods in Geography subjects. In addition, the selection of learning methods that are not yet right will affect student learning outcomes that are less than optimal. Conventional methods such as lectures used by teachers require more modern reforms to adapt to $21 \mathrm{st}$ century learning so that students become interested in following the learning process.

The learning process requires positive interaction between the teacher and students, so that two-way communication will be realized in a conducive atmosphere and there is a balance between the freedom of students to express their feelings and the authority of the teacher [2]. The student-centered learning process (student center) will be able to make students more active in participating in class because in classroom learning it is not only a teacher who can convey knowledge to students, but students can also express opinions about knowledge or experience according to the learning process. being studied. Then students can also practice directly about the understanding that has been learned before by implementing it directly in everyday life, so that students can learn cognitive, affective and psychomotor. The problem in studying Geography subject matter is knowledge that is still 
considered difficult to understand because it is only studying theory without implementing it, so that it causes students to be confused in studying Geography subjects because they cannot align theoretical knowledge through direct Simulation learning. The main material that requires Simulation learning is mitigation and adaptation to natural disasters.

This is based on Indonesia's territorial background from a disaster perspective. Indonesia is a country that is prone to natural disasters. According to Law Number 24 of 2007, Natural disasters are disasters caused by events or a series of events caused by the natural environment, including floods, tsunamis, volcanic eruptions, floods, droughts, hurricanes, and landslides.. This is because the Indonesian region is geologically traversed by three tectonic plates of the world, namely the Australian plate, the Pacific plate, and the Eurasian plate [3]. Disasters that often occur in Indonesia are floods because of an archipelagic country. Floods are the original vibrations from within the earth, originating in the earth which then propagate to the earth's surface due to the fracture of the earth breaking and shifting violently. Flood disaster is a natural disaster that has a wide reach and cannot be estimated at the time of its occurrence. Flood disasters can cause various losses such as casualties, injuries, property losses and psychological effects. Several floods have been recorded in Indonesia, such as the Aceh earthquake, the Yogyakarta earthquake, the Padang earthquake, and the Palu earthquake [4]. The reason the researcher chooses the subject matter of natural disaster mitigation and adaptation in class XI IPS is the right material to use the Simulation learning method because the learning requires direct and real implementation. The next reason is because this material is the latest material for the 2013 Curriculum which has been revised, because in the previous curriculum, namely the 2013 Curriculum, natural disaster mitigation material has not been included in the Geographical Competence of class XI IPS, so the results of this study can help teachers in developing learning methods. Researchers will test the Simulation learning method in improving student learning outcomes in terms of cognitive (knowledge), affective (attitude), and psychomotor (action) in dealing with the flood disaster, so that it can be compared with conventional methods. Then this research was carried out at SMA N 8 Semarang because based on the results of the 2020 BNPB Disaster Risk Study it was stated that the city of Semarang was included in the high risk class for flood disasters [5].
Simulation learning is a learning model that involves students directly participating in the learning process. The Simulation learning model takes the concept from Ferdinand Brunetiere and Balthazar [7]. According to him, drama is an art that depicts human nature and attitudes through action (movement of players on stage) and behavior. In this case, students act as actors who carry out activities that focus on imagining to achieve the learning objectives carried out. Learning activities by role playing encourage students to express their feelings based on the assumption that it is possible to create authentic similarities into real life problem situations. The choice of a Simulation learning model can minimize and overcome problems related to the inactivity of students in learning [8]. In the learning process using a Simulation learning model, students are invited to learn while demonstrating roles, students can practice directly how the stages of mitigation in dealing with natural disasters, starting from before, during and after the disaster. So that the classroom atmosphere will feel alive because the elements that exist in students will be maximized to work both cognitive, affective, psychomotor and audio elements [9].

\section{METHODS}

The research location is in SMA N 8 Semarang, the research population is all class XI IPS. This study used purposive sample sampling technique, namely sampling by taking the subject not based on strata, random or regional but based on the existence of certain objectives. The sample taken was a number of 73 students from class XI IPS 3 as the experimental class and class XI IPS 4 as the control class. Methods of data collection using the method of documentation, questionnaires, tests, and observations. The data analysis technique used percentage description analysis. The results of the test validity showed 21 questions were valid out of 30 questions, then the affective questionnaire with 4 valid indicators, and a psychomotor questionnaire with 3 valid indicators. The validity criteria are very high.

\section{RESULTS AND DISCUSSION}

\subsection{Implementation of Simulation Learning Learning Methods for Flood Disaster}

The learning method of Flood Simulation learning is implemented into the subject matter of natural disaster mitigation and adaptation. Based on the calculation of the observation sheet, the percentage 
descriptive results were $95.49 \%$ which was considered a very high criterion. The learning method activities of the Flood Disaster Simulation Learning are carried out on Monday and Wednesday according to the Geography lesson for class XI IPS 3.

The implementation of Simulation learning method is measured by using the observation sheet instrument and observed by the observer. The calculation of the observation sheet used a descriptive percentage with a score of $95.49 \%$, so it was considered a very high criterion. So that in the observation sheet because the implementation of the Simulation Learning learning method for the Flood disaster has been implemented systematically, most of the answers are "Yes" with a score of 1 for each statement from observers who observed the course of Simulation learning activities carried out by researchers.

The implementation of the Flood disaster Simulation Learning learning method has been carried out in five meetings in the experimental class. Based on the results of research that has been carried out, it is found that the results of the descriptive calculation of the percentage of Simulation learning method using the observation sheet instrument obtained $95.49 \%$ which is included in the very high criteria. This is caused by various factors, from Simulation learning methods, researchers, and infrastructure.

The learning method for Simulation Learning for Flood disaster is the main factor that determines the percentage descriptive score acquisition that falls into the very high criteria. The observation sheet instrument made by the researcher consisted of questions about the implementation of the Flood Simulation Learning learning method that had been implemented. Researchers have made observation sheets according to procedures and systematically sourced from the disaster preparedness training manual of the National Disaster Management Agency (BNPB).

The descriptive results of a very high percentage were also influenced by students in the experimental class. The influence of students in the experimental class is because all students participate in the implementation of Simulation learning method activities from the first to the fifth meeting. So that all students have known about the procedures that must be carried out in learning activities with the Simulation learning method. Students who did not answer "Yes", the causes were such as being sick, not paying attention to instructions from researchers, and lacking understanding of the Flood disaster Simulation Learning learning method.

The infrastructure used in the implementation of the research influenced the descriptive results of the percentage of the implementation of the Simulation Learning Flood learning method. Facilities such as those that must be carried by each group are different, thus affecting students' understanding in answering the statements in the observation sheet. The statement of students who do not understand the infrastructure causes the percentage descriptive result to be $95.49 \%$.

The learning method of Flood Simulation learning is divided into 3 stages, namely pre, during, and postdisaster. The implementation of Simulation learning method is implemented using role playing method, where all students play roles by dividing into 5 groups. Each group consists of 6-7 students with their respective roles. The function of the researcher divides 37 students into 5 groups is to facilitate coordination in Simulation learning activities for the Flood disaster.

The learning method used in Simulation learning is in accordance with the procedure and systematically so that students will not be confused in applying it. Researchers used the theme of disaster, namely floods in accordance with the main material being taught. The implementation of Simulation learning methods is taught systematically and gradually so that students can understand deeply about how to deal with flood disasters, especially in schools [8]. The implementation of Simulation learning methods involves researchers, teachers of Geography, UKS management teachers, PMR organizations, office boys, and security guards. The method of Simulation learning cannot be implemented by researchers alone because it requires infrastructure, activity permits, and security during the Simulation Learning activities of the Flood disaster.

\subsection{Student Learning Outcomes}

Student learning outcomes in the experimental class were calculated using descriptive percentages. The calculated learning outcomes consist of cognitive (knowledge), affective (attitude), and psychomotor (action) aspects. The following are the results of the calculation of the experimental class learning outcomes:

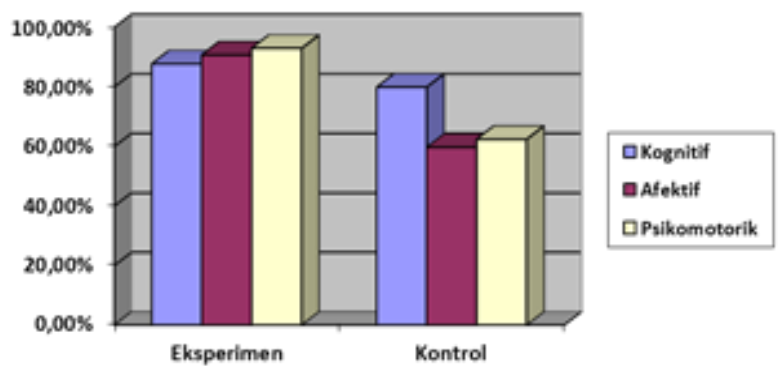

Figure 1. Student Learning Outcomes in Experiment Class

Based on the data above, it can be explained that the experimental class obtained learning outcomes in the cognitive aspects of a score of $87.77 \%$ including very high criteria, $90.74 \%$ affective aspects including very 
high criteria, and cognitive aspects of $90.74 \%$ including very high criteria. While the control class obtained learning outcomes in cognitive aspects of $79.94 \%$ including high criteria, affective aspects of $59.76 \%$ including moderate criteria, and psychomotor aspects of $62.43 \%$ including moderate criteria. The research data above, from the three aspects of student learning outcomes, shows that the comparison of the experimental class learning outcomes is higher than the control class. Comparison of affective and psychomotor learning outcomes reaches $30 \%$.

Student learning outcomes are carried out in the experimental class and the control class. The experimental class, namely class XI IPS 3, used Simulation learning methods and the control class, namely class XI IPS 4, used varied lecture learning methods from Geography teaching teachers in schools. Based on the learning outcomes of the control class from the cognitive aspect, it got a score of $79.94 \%$ which included high criteria, affective aspects with a score of $59.76 \%$ which included moderate criteria, and psychomotor aspects with a score of $62.43 \%$ which included moderate criteria. Then for the experimental class student learning outcomes from the cognitive aspect it has a score of $87.77 \%$ with very high criteria, affective aspects with a score of $90.74 \%$ with very high criteria, and psychomotor aspects with a score of $93.00 \%$ with very high criteria.

Based on the descriptive percentage of student learning outcomes from the two classes, it can be analyzed that the experimental class has a higher learning outcome score than the control class. The experimental class with a total of 37 students has a score that includes very high criteria compared to the control class with high and medium criteria. Learning outcomes that have the least percentage difference are from the cognitive aspect (knowledge) which has a difference of $7.83 \%$. Then for the affective aspect (attitude) has a difference of $30.98 \%$, and the psychomotor aspect (action) has a difference of $30.57 \%$.

Learning outcomes with cognitive aspects were measured using a test instrument consisting of 30 multiple choice questions. The analysis of learning outcomes between the experimental class and the control class has clear differences when students answer the mitigation questions during the disaster and postdisaster stages. The experimental class answered more questions correctly than the control class, such as the example question like in number 17 , which is a question about the basic color used to make the evacuation route board. The experimental class has implemented the prestage Simulation Learning of natural disasters by making evacuation route boards so that all students know the answers to these questions. Then 19, the example of the test questions is asking about disaster mitigation steps while on the 2 nd floor. The experiment class has been taught how to apply the Simulation learning of the Flood disaster when on the 2nd floor.

The affective learning outcomes (attitudes) of the experimental class were higher than the control class. The criteria for affective learning outcomes in the experimental class were very high, while the control class was included in the moderate criteria. The difference in the descriptive score of the percentage of affective learning outcomes reached $30.98 \%$. The factors that influence the differences in learning outcomes are the implementation of the learning methods used by researchers. The experimental class has higher learning outcomes because it implements Simulation learning which can shape and improve attitudes in flood disaster mitigation. Attitude learning outcomes are measured using a questionnaire instrument, in the questionnaire there are criteria and scores, namely (1) unskilled, (2) less skilled, (3) sufficiently skilled, (4) skilled, (5) very skilled. The total score of the experimental class was 5986 out of 37 students, while the control class had a score of 3981 out of 34 students. The affective learning outcomes (attitudes) of the experimental class which were superior to the control class were supported by the teaching and learning activities carried out by the researcher. Supporting factors such as knowing and participating in making documents needed in Simulation Learning for the Flood disaster, carrying out action plan activities that will be implemented in schools, and complying with procedural rules during Simulation learning activities take place. So that most students in the experimental class answered the questionnaire with the answer (5) Very skilled, while students in the control class mostly answered by choosing (3) Sufficiently skilled because students were not taught Simulation learning or direct practice about attitudes that must be implemented in disaster mitigation. Flood.

Psychomotor learning outcomes (action) were measured using a questionnaire instrument. The scoring criteria used are the same as the attitude measurement. Psychomotor learning outcomes (action) questionnaire has 4 indicators. The experimental class had a total score of 4607 out of 37 students, while the control class had a total score of 3132 out of 34 students. Psychomotor learning outcomes (action) between the experimental class and the control class have a percentage difference that is almost the same as the affective learning outcomes (attitudes). The difference in learning outcomes in the two classes is because students in the experimental class as a whole have been taught about mitigation measures in overcoming flood risk in schools starting from the pre, during, and postdisaster stages. Students in the experimental class have participated in a series of activities for 3 core meetings so that they understand and know how to practice in accordance with the theory that has been learned. 


\subsection{Strengths and Weaknesses of Simulation Learning Methods}

The learning method of Simulation learning has advantages over the conventional learning methods applied by teaching teachers in the control class. The advantage of Simulation learning methods in the subject matter of natural disaster mitigation and adaptation is that students directly practice or direct Simulation learning by playing a role in flood disaster mitigation. Then students are also more active in Geography learning activities, then students can remember the subject matter as well as practice it directly.

Based on the results of this study, it was analyzed that learning the subject matter of natural disaster mitigation and adaptation in the classroom was influenced by the learning method used. The difference in cognitive learning outcomes (knowledge) tends to be relatively the smallest because it uses theory and the instruments used are tests. The knowledge of students in both classes about the subject matter of flood disaster mitigation tends to be the same. Then the difference is the learning outcomes in terms of affective (attitude) and psychomotor (action) aspects where the control class has a higher percentage descriptive score than the experimental class. The control class has superior affective (attitude) and psychomotor (action) learning outcomes because students can directly practice or dramatize the knowledge that has been obtained from theories about flood disaster mitigation, especially in schools. Meanwhile, the control class is taught about cognitive aspects (knowledge) so that most students only have the ability to memorize without doing Simulation learning directly in the field.

\section{CONCLUSION}

Based on the results of research and data collection in the field, it can be concluded that the implementation of the Flood Disaster Simulation Learning learning method can improve student learning outcomes from the cognitive (knowledge) aspects of students, affective (attitudes), and psychomotor (actions) behavior of students in dealing with disasters. The increase in student learning outcomes in the experimental class is caused by the ability of students to understand real natural disaster mitigation and adaptation materials that exist in the field or in the real world. Overall student learning outcomes in the experimental class were higher than those in the control class. Three aspects of student learning outcomes in the experimental class are included in the very high criteria. So, for the implementation of the learning simulation learning method, it can be applied in the material for mitigation and adaptation of natural disasters in class XI IPS of Senior High School.

\section{REFERENCES}

[1] Lubis, Kun Marlina. 2013. Peningkatan Aktivitas Pembelajaran Hidrosfer Dan Dampaknya Terhadap Kehidupan Melalui Tindakan Guru Inovatif Pada Kelas X Di SMA Negeri 1 Semarang. Jurnal Geografi, Volume 10 No. 2: 189-202

[2] Sholeh, Muh. 2007. Perencanaan Pembelajaran Mata Pelajaran Geografi Tingkat SMA Dalam Konteks KTSP. Jurnal Geografi FIS UNNES, Volume 4 No.2: 129-137.

[3] Undang-Undang Republik Indonesia Nomor 24 Tahun 2007 Tentang Penanggulangan Bencana

[4] Rochmah, Aini Nur Khoirurrizqi. 2017. Pembelajaran Mitigasi Bencana Melalui Media Audio Visual Pada Kelas X Di SMA Negeri 10 Semarang. Skripsi. Semarang: Fakultas Ilmu Sosial UNNES

[5] Badan Nasional Penanggulangan Bencana. 2020. Buku Pedoman Latihan Kesiapsiagaan Bencana Membangun Kesadaran, Kewaspadaan, dan Kesiapsiagaan Dalam Menghadapi Bencana. Jakarta: BNPB.

[6] Peraturan Kepala Badan Nasional Penanggulangan Bencana Nomor 04 Tahun 2012 Tanggal 30 April 2012.

[7] Risalati, Nur. 2018. Penerapan Model Pembelajaran Simulation Learning Dalam Meningkatkan Aktivitas Belajar Siswa Pada Mata Pelajaran Ips: Penelitian Tindakan Kelas IV di MI YLPI'Ibaadurrahman. Skripsi. Bandung: UIN Sunan Gunung Djati

[8] Hayudityas, Beatrix. 2020. Pentingnya Penerapan Pendidikan Mitigasu Bencana di Sekolah Untuk Mengetahui Kesiapsiagaan Peserta Didik. Edukasi Nonformaldukasi Nonformal 1(2): 94-102

[9] Sri, Komang, U. 2018. Pengaruh Model Simulation Learning Berbantuan Boneka Tangan Terhadap ketrampilan Berbicara. Journal of Education Technology. 2(4): 153-159. 